\title{
Factors associated with occupational roles in older Brazilians: a cross-sectional pilot study
}

\author{
Carolina Rebellato ${ }^{a}$, Maria Luisa Guillaumon Emmel ${ }^{\mathrm{b}}$, \\ Júnia Jorge Rjeille Cordeiroc ${ }^{c}$ Jorge Oishi ${ }^{a}$ \\ ${ }^{a}$ Universidade Federal de São Carlos - UFSCar, São Carlos, SP, Brazil. \\ bPrograma de Pós-Graduação em Terapia Ocupacional, Universidade Federal de São Carlos - UFSCar, \\ São Carlos, SP, Brazil. \\ ${ }^{c}$ Faculdade de Ciências da Saúde - FACIS, Instituto Israelita de Ensino e Pesquisa Albert Einstein - IIEPAE, \\ São Paulo, SP, Brazil.
}

\begin{abstract}
Introduction: The Gerontology points out concerns in understanding aging and its consequences, in order to propose specific policies. Objective: Identify occupational roles of older Brazilians and the relationship of these roles to demographic, socioeconomic, and health factors. Method: Participants included 67 non-institutionalized individuals 70-84 years of age (33 men and 34 women; average age: 74.6 years). The roles performed in the Past, Present and Future were examined using the Role Checklist. Results: The occupational roles have changed over time, evidencing the loss of roles during the transition from Past to Present, although the participants stated that they intend to be engaged in a higher number of roles in the Future. The main roles performed in the Present are Hobbyist/Amateur, Home Maintainer and Family Member. In general, engaging in occupational roles was associated with higher education and income either in the Past, Present and Future. Conclusions: The study enabled to detect the diversity and complexity of older people's participation in society, contributing to a further understanding of their occupational careers. The main limitation of this study concerns to the specific sample composition, with independent older people. Further studies are in need to obtain an in-depth theoretical and empirical understanding of the trends and trajectories of the roles of older people.
\end{abstract}

Keywords: Aged, Geriatrics, Occupational Therapy, Socioeconomic Factors.

\section{Fatores associados com papéis ocupacionais em idosos brasileiros: um estudo piloto transversal}

Resumo: Introdução: A Gerontologia aponta a preocupação em compreender o envelhecimento e suas consequências, visando a propor políticas específicas. Objetivo: Identificar os papéis ocupacionais na velhice e a sua relação com os fatores demográficos, socioeconômicos e de saúde. Método: Participaram 67 idosos não institucionalizados de 70 a 84 anos de idade (33 homens e 34 mulheres; idade média: 74,6 anos). Os papéis desempenhados nos tempos Passado, Presente e Futuro foram analisados usando-se a Lista de Identificação de Papéis Ocupacionais. Resultados: Os papéis ocupacionais mudaram ao longo do tempo, evidenciando a perda de papéis durante a transição do Passado para o Presente, embora exista o interesse em ampliá-los no Futuro. Os principais papéis desempenhados no Presente foram Passatempo/Amador, Serviço doméstico e Membro de família. Em geral, o engajamento em papéis ocupacionais foi associado com maior escolaridade e renda, igualmente nos tempos Passado, Presente e Futuro. Conclusão: O estudo permitiu detectar a diversidade e a complexidade da participação das pessoas idosas na sociedade, contribuindo para uma maior compreensão de sua carreira ocupacional. A principal limitação do estudo refere-se à composição específica da amostra, composta de pessoas idosas independentes. Mais estudos são sugeridos para aprofundamento teórico e empírico, visando ao acompanhamento de tendências e trajetórias do envelhecimento.

Palavras-chave: Idoso, Geriatria, Terapia Ocupacional, Fatores Socioeconômicos.

Corresponding author: Carolina Rebellato, Universidade Federal de São Carlos, Rodovia Washington Luis, Km 235, Monjolinho, CEP 13565-905, São Carlos, SP, Brasil, e-mail: carorebellato@ig.com.br 


\section{Introduction}

In Brazil the number of older adults is over 20 million, corresponding to $10.8 \%$ of the population (INSTITUTO..., 2011). In the next 15 years, the Brazilian population over 60 years old may exceed 32 million, representing almost $13 \%$ of the population in 2024 (INSTITUTO..., 2009). Such demographic change has motivated several research studies because it is happening very rapidly and without appropriate preparation (VERAS, 2009). According to Freitas et al. (2002), few problems have necessitated so much attention and concern as the process of aging.

Aging, from a didactic perspective, is understood by analyzing four interconnected domains: the chronological, biological, psychological, and social domains (QUEIROZ; PAPALÉO NETTO, 2007). Social aging is characterized by a process of change in social roles, and consequently, certain behaviors are expected of people of certain ages at a given point in history for each society (MCLNTYRE; ATWAL, 2007; IRIGARAY; SCHNEIDER, 2008).

Role definitions come from role theory, a subfield of social psychology. The concept of role is complex, but, from this perspective, social roles refer to a set of behaviors that are expected and/or engaged in by a person in certain context. The social roles are divided into three types: personal-sexual, social-familial, and occupational (OAKLEY et al., 1986).

In general, the intervention of the occupational therapist focuses on the reciprocal relationship between the involvement in occupations and the health and well-being aspects of the individuals (AMERICAN..., 2008). Occupational therapy primarily addresses the person's occupational roles in treatment, but does not exclude the personal-sexual or social-familiar dimensions (OAKLEY et al., 1986; DICKERSON; OAKLEY, 1995; CORDEIRO et al., 2007).

In occupational therapy, the occupational role was applied more intensely as it became an essential component of theoretical reference, the Model of Human Occupation, created by Gary Kielhofner. In this model, occupational roles, component of the subsystem of volition, are defined as the images people have of themselves as occupying certain positions in social groups, and obligations and expectations that accompany being in those roles. Therefore, the occupational roles organize occupational behavior to meet needs and demands of both person and society (BRÄNHOLM; FUGL-MEYER, 1994; KIELHOFNER, 2008).
The occupational roles people choose and perform throughout life influence them in the organization of their daily occupations, such as where individuals go, which occupations they are engaged in, the kinds of interpersonal relationships that develop, and how time and money are spent, thus contributing to self-identity, sense of satisfaction, and individual self-efficacy (BRÄNHOLM; FUGL-MEYER, 1994; HAKANSSON et al., 2005; KIELHOFNER, 2008).

Occupational roles change according to age, gender, life and work conditions, interests, culture, and moment in history, among other factors (BLACK, 1976; HAKANSSON et al., 2005; NERI, 2008). Interruptions and imbalance in occupational roles due to expected or unexpected lifecycle events represent critical adaptive processes for individuals who experience the changes in different areas of life (DICKERSON; OAKLEY, 1995; CORDEIRO, 2005).

According to Baltes and Baltes (1991), successful aging is the individual's adaptation process to the changes associated with aging through psychological mechanisms of selection, optimization, and compensation. The selection consists of determining goals according to each individual's biopsychosocial conditions. The optimization aims at empowering internal and external resources to reach the highest functional levels within those selected goals. Lastly, the compensation involves the adoption of alternative methods or tasks to maintain the functioning of the individual (BALTES; BALTES, 1991).

The implementation of active aging policy proposed by the World Health Organization, [WHO], 2005, has led to discussions on the social involvement of older individuals to improve quality of life. The continuous participation or engagement of individuals, along with safety and health, is the basis for active aging (ORGANIZAÇÃO..., 2005). Although world current trends in programs and policies aimed for the older population highlight the importance of remaining active to maintain health and quality of life, regardless of different approaches and ideologies, there is a limited understanding regarding the social and preventive importance that an active lifestyle may have on aging in the Brazilian context. Hence, this establishes the importance of exploring the older people's activity patterns, mainly for the purpose of interventions (RIBEIRO et al., 2009).

Specific studies regarding occupational roles in old age were conducted by Elliott and Barris (1987), Watson and Ager (1991), and McKenna, Broome and Liddle (2007); these studies used different methodologies and obtained conflicting results with regard to the correlation between occupational roles 
and satisfaction in life. Although not current, those studies show similarities in relation to performance and the value of occupational roles. Both studies used the Role Checklist (OAKLEY et al., 1986) to evaluate the participants' occupational roles. This instrument was created by Occupational therapist Frances Oakley and collaborators, and it was based on the Model of Human Occupation theory (KIELHOFNER, 2008).

Elliott and Barris (1987) included 112 Americans aged 65 or older to explore the relationship between the number of occupational roles and their respective degrees of importance for satisfaction in life. They showed changes in the elderly occupational behaviors between the Past and the Present. The main lost roles were Worker, Student, and Volunteer, while roles such as Home Maintainer, Friend, Family Member, Religious Participant, and Hobbyist/Amateur were gained and were given higher values. The results generally showed a positive correlation between the number of occupational roles performed and their respective degrees of importance to satisfaction in life.

The study by Watson and Ager (1991), which involved 75 Americans aged 50-90 years old, shows that the participants performed more frequently the roles of Home Maintainer, Family Member, and Friend, and they attributed more importance to these roles. Although the previous hypothesis of correlation between the frequency of occupational roles and satisfaction in life was not supported, the authors highlighted that deeper research regarding this matter is essential for occupational therapy, as it may promote a better understanding on the influence of occupational roles in people's lives, enabling a more effective planning and intervention of specific programs for older adults.

McKenna, Broome and Liddle (2007) studied 195 Australians aged 65 years or older and verified changes in use of time and occupational roles as age increased and the relationship between these two aspects and satisfaction in life. With regard to occupational roles, the older people increasingly participated in the roles of Friend, Family Member, Home Maintainer, and Hobbyist/Amateur, and the main roles they valued are Family Member and Friend. In general, this showed that increasing age does not seem to reduce engagement in occupational roles, and maintenance of the occupational roles was significantly related to greater life satisfaction in participants aged 75- 84 years.

McKenna, Broome and Liddle (2007) emphasized that there are few studies regarding occupational roles in old age and described some reasons for such research. According to the authors, understanding of occupational roles may help us to understand the composition and breadth of the daily occupations of the older people in order to define therapeutic objectives, compare populations, and enable the rejection of negative stereotypes that are still attributed to aged individuals.

A literature review was conducted at Bireme (CENTRO..., 2014) through an integrated method by selecting all index and sources with the descriptor "occupational role" refined by "elderly" in the limits group. Occupational therapy journals at the University of São Paulo (REVISTA..., 2014) and the Federal University of São Carlos (CADERNOS..., 2014), in addition to the dissertation and thesis databases of the Brazilian Institute for Scientific and Technological Information (INSTITUTO..., 2014) and CAPES (COORDENAÇÃO..., 2014), were also analyzed by searching for the expression "occupational role." No scientific research on occupational roles during old age in Brazil has been identified to date.

Facing the lack of studies associated with the potential of the investigative practice of occupational therapy and the promotion of active aging as a world trend, it is of fundamental importance to know the occupational roles of the older Brazilians and their relationship with demographic, socioeconomic and health factors.

\section{Method}

The delineation of the study was exploratory, descriptive and cross-sectional with quantitative approach. This choice was considered most appropriate to meet the study aims, taking into account the time and the financial resources available.

\subsection{Participants}

A convenience sample of sixty-seven noninstitutionalized individuals between the ages of 70 and 84 years old volunteered for the study. The exclusion criteria were limitations that made it impossible to communicate following the interviewer's perception; cognitive impairment, characterized by a score of less than 19 points for illiterate individuals and below 25 for those with past school experience on the Mini-Mental State Examination (MMSE), and dependence in basic activities of daily living, as evidenced by individuals whose score is under 5 points on the Katz scale. 


\subsection{Context}

The study was conducted on older adults from an Association of Retirees located in a medium-sized city in the central-western region of the State of São Paulo, Brazil. The municipality has approximately 118,843 inhabitants, of which 14,854 (12.5\%) are aged individuals (INSTITUTO..., 2011).

\subsection{Instruments}

\subsubsection{Demographic, socioeconomic, and health data}

The identification form included the following self-reported variables: gender, age, race, religion, marital status, schooling (years of study), monthly income and per capita monthly household income (minimum wage ${ }^{1}$ ), occupational status, family arrangement, practice of physical activity, and the presence and number of reported illnesses.

\subsubsection{Mini-Mental Status Exam (MMSE)}

The MMSE (FOLSTEIN; FOLSTEIN; MCHUGH, 1975 ) is an instrument used worldwide to track cognitive impairments (BRUCKI et al., 2003). It is comprised of 30 categorical questions. MMSE scores may vary from $0-30$ points with lower scores indicative of cognitive impairment (VIEIRA; KOENING, 2002). The exam aimed to exclude individuals with probable cognitive impairment, since the results could be jeopardized by their difficulty in comprehending the questions. As already mentioned above, the cutoff score used was equal or above 19 points (for individuals with zero years of study) or of 25 or more points (for individuals who had attended school) (LOURENÇO; VERAS, 2006).

\subsubsection{Katz scale}

The Katz scale is comprised of six items measuring the individual's performance on basic activities of daily living, conceptualized as follows: feeding, continence, transfer, toileting, dressing and bathing (KATZ; AKPOM, 1976). The score is the number of "yes" answers (independent in performing the task). Scores may vary from 0 to 6 points, where 6 means independent, 4 indicates partial dependence, and 2 indicates significant dependence. Based on self-report, individuals with dependence in basic activities of daily living were excluded, since studies in this area confirm the positive relationship between independence and social engagement (RIBEIRO et al., 2009). Therefore only individuals whose scores were 5 or 6 participated in this research (BRITO; NUNES; YUASO, 2007).

\subsubsection{Geriatric Depression Scale with 15 items (GDS-15)}

Created by Yesavage and Sheikh (1986), the GDS-15 is reduced version from the 30 item original instrument used to track the symptoms of depression in aged individuals. It is comprised of 15 objective questions containing dichotomous "yes" or " $n o$ " answers. Each affirmative answer adds one point to the score, which may vary between 0 and 15 points (high scores indicate the potential presence of depression). Since depression among older adults occurs in high numbers, even on non-institutionalized individuals (BLAZER, 2009), it was decided not to utilize this scale as a criteria for exclusion, but to characterize and to analyze the older adults, that is, as an independent variable. The individuals who came up with scores between 0 and 5 were considered non-depressive symptomatology individuals and the ones who had scores between 6 and 15 were symptomatology depressive (PARADELA; LOURENÇO; VERAS, 2005).

\subsubsection{Role checklist}

This instrument is utilized to obtain information as to the perception of an individual in occupational roles throughout life and the degree of importance attributed to each role. It consists of a written inventory divided into two parts that requires approximately 15 minutes to complete. Part I identifies occupational roles in the Past, Present, and Future. Part II identifies the degree of importance attributed to each role, with the options: Not at all valuable, Somewhat valuable, or Very valuable. Occupational roles are briefly defined and divided in a simple, standard manner: Student, Worker, Volunteer, Caregiver, Home Maintainer, Friend, Family Member, Religious Participant, Hobbyist/Amateur, and Participant in Organizations. The frequency At least once a week is included in the definition of all roles, except the Student and Worker, whose performance is linked to the frequency Part time or full time (OAKLEY et al., 1986; CORDEIRO, 2005).

The time scheme used for this study was:

- Past: ages 40-60 years;

- Present: includes the last week, including today; and

- Future: any point in time after tomorrow. 
Present and Future were defined according to the delimitation of Oakley et al. (1986). In Past delimitation, lower limit of 40 years old, was determined by the studies of Watson and Ager (1991), and the age of 60 years old marked the end of that period, since it is the age that classifies a person as an older adult in the Brazilian society.

In terms of reliability of the original instrument in English, the authors applied the instrument in two distinct occasions in a group of 124 healthy adults between $18-79$ years of age (average age: 33.5 years). The concordance between occupational roles varied from 86 to $89 \%$ on Part I and it obtained the average of $79 \%$ on Part II. The numbers obtained from kappa and weighted kappa suggested concordance measures from moderate to almost perfect in most results in Part I and Part II, hence it shows to have satisfactory reliable results test-retest (OAKLEY et al., 1986).

In Brazil, the validation of this instrument involved a sample of 25 patients (average age 65.7 $[\mathrm{SD}=9.3]$ years old) with Chronic Obstructive Pulmonary Disease (COPD). The concordance percentage between occupational roles showed results that can be compared to the ones obtained in the study of the original instrument. The Brazilian study obtained fluctuations from 84 to $91 \%$ in average concordance in Part I and 75\% in Part II. As well as in the North American Study, this study obtained moderate to almost perfect concordance in most roles in Part I and Part II of the instruments. Therefore, the results were considered satisfactory in test-retest (CORDEIRO et al., 2007).

The Role Checklist was used since it is the only instrument that evaluates occupational roles translated and validated in Brazil; it is easy to use and quickly applied to different individuals in several countries (CORDEIRO, 2005). Furthermore, this assessment has been used clinically and is the most widely accepted role assessment utilized by occupational therapists (VAUSE-EARLAND, 1991).

\subsection{Procedure}

In this initial project, $19.1 \%$ refused participation in the study, $7.4 \%$ did not meet the inclusion criteria, and $18.4 \%$ were lost because of participation in the pilot study, turning 85 years old, death, or lack of contact.

Seventy-five members scheduled their interviews in accordance with time preference and availability. Eight out of seventy-five members (10.7\%) were excluded in face to face contact with the interviewer based on the results of the MMSE and/or the Katz Scale, and therefore they did not continue the interview. The ones who met the eligibility criteria, $(\mathrm{N}=67)$, proceeded with the interview by filling out the identification form, application of GDS-15 and Role Checklist. All the data, including the identification form, was obtained during the interview and the forms were filled out by the researcher. The interviews took place at the subject's home. Each appointment lasted approximately 35 minutes.

\subsection{Statistical analysis}

The data were initially submitted to descriptive statistical analysis. Chi-square and Fisher's Exact tests were used to compare categorical variables. Ordinal data were analyzed using Wilcoxon and Friedman nonparametric statistical tests. Statistics were considered significant if $\mathrm{p} \leq .05$. The computational tool used was Statistics 8.0.

\section{Results}

\subsection{Sample characteristics}

The final sample consisted of 67 individuals (34 [50.7\%] females and 33 [49.3\%] males). Participants' average age was $74.6(\mathrm{SD}=3.7)$ and average years of schooling was 6.2 years $(\mathrm{SD}=4.7)$. The average participant was married, earned a monthly income of up to 3 times the minimum wage, was professionally inactive, lived with others, performed physical activities regularly, and did not present depressive symptomatology according to the GDS-15. Forty subjects (59.7\%) had some type of illness, and the average number of illnesses in the total sample was $1(\mathrm{SD}=1.1)($ Table 1$)$.

\subsection{Occupational roles}

The older adults lost occupational roles when Past-Present and Past-Future were compared, but they intended to engage in a higher number of roles in the transition between Present-Future (Table 2).

In the Past, the most common roles were Worker, Family Member, and Hobbyist/Amateur. In the Present and Future, the elderly most commonly performed the role of Hobbyist/Amateur, followed by Home Maintainer (Table 3).

\subsection{Value attributed to occupational roles}

The participants highly valued all the occupational roles. They regarded them Very valuable, especially the Student, Family Member and Hobbyst/Amateur roles. The Participant in organization role was the one most frequently mentioned in the category Not at all valuable (25\%) (Table 4). 
Table 1. Characteristics of the sample $(n=67)$.

\begin{tabular}{|c|c|c|c|}
\hline \multicolumn{2}{|c|}{ CHARACTERISTICS } & \multirow{2}{*}{$\frac{\mathrm{n}}{33}$} & \multirow{2}{*}{$\frac{\%}{49.3}$} \\
\hline Gender & Male & & \\
\hline & Female & 34 & 50.7 \\
\hline Age (years) & $70-74$ & 37 & 55.2 \\
\hline \multirow[t]{2}{*}{ Mean $74.6(\mathrm{SD}=3.7)$} & $75-79$ & 19 & 28.5 \\
\hline & $80-84$ & 11 & 16.4 \\
\hline \multirow[t]{2}{*}{ Race } & White & 62 & 92.5 \\
\hline & Black & 5 & 7.5 \\
\hline \multirow[t]{2}{*}{ Religion } & Catholic & 54 & 80.6 \\
\hline & Non-Catholic & 13 & 19.4 \\
\hline \multirow[t]{2}{*}{ Marital status } & Married & 47 & 70.0 \\
\hline & Non-married ${ }^{1 *}$ & 20 & 30.0 \\
\hline Education (years) & $0-3$ & 15 & 22.4 \\
\hline Mean $6.2(\mathrm{SD}=4.7)$ & $4-7$ & 33 & 49.2 \\
\hline Median 4.0 [0-24] & +8 & 19 & 28.4 \\
\hline Income & $<3$ & 39 & 58.2 \\
\hline \multirow[t]{2}{*}{ (minimum wage) } & $3-5$ & 15 & 22.4 \\
\hline & $>5$ & 13 & 19.4 \\
\hline $\begin{array}{l}\text { Per capita household } \\
\text { income }\end{array}$ & $<1$ & 4 & 6.0 \\
\hline \multirow[t]{2}{*}{ (minimum wage) } & $1-2$ & 21 & 31.3 \\
\hline & $>2$ & 42 & 62.7 \\
\hline \multirow[t]{2}{*}{ Occupational status } & Active $^{2 *}$ & 17 & 25.4 \\
\hline & Inactive $^{2 * *}$ & 50 & 74.6 \\
\hline \multirow[t]{2}{*}{ Family arrangement } & Live alone & 8 & 12.0 \\
\hline & Accompanied & 59 & 88.0 \\
\hline \multirow{2}{*}{$\begin{array}{l}\text { Presence of } \\
\text { depressive } \\
\text { symptoms }\end{array}$} & Yes & 7 & 10.4 \\
\hline & No & 60 & 89.6 \\
\hline \multirow{2}{*}{$\begin{array}{l}\text { Presence of illnesses } \\
\text { (self-reported) }\end{array}$} & Yes & 40 & 59.7 \\
\hline & No & 27 & 40.3 \\
\hline \multirow[t]{2}{*}{$\begin{array}{c}\text { Practice of physical } \\
\text { activity }\end{array}$} & $\begin{array}{c}\text { Non- } \\
\text { sedentary }\end{array}$ & 37 & 55.2 \\
\hline & Sedentary ${ }^{3 * *}$ & 30 & 44.8 \\
\hline
\end{tabular}

Note: SD - Standard Deviation. ${ }^{1 *}$ Non-married - includes widowed, single and divorced. ${ }^{2 *}$ Active - individuals who continue to work after retirement. ${ }^{2 * *}$ Inactive - individuals who do not work. ${ }^{3 *}$ Non-sedentary - individuals who practice sports regularly (from 1 to 5 times a week). ${ }^{3 * *}$ Sedentary - individuals who rarely or never practice sports. Source: Elaborated by the authors.

\subsection{Occupational roles, demographic, socioeconomic, and health data}

In general, occupational roles were associated with various demographic, socioeconomic, and health factors in Past, Present and Future. Tables 5, 6 and 7 demonstrate which occupational roles were associated to subgroups of each studied variable. For example, when regarding Past, the Work role is performed significantly more by men while the Caregiver, Home Maintainer and Family Member roles performed in much more evidence by women. In Present and Future, we could observe that older adults who earn monthly income over 5 minimum salaries, are significantly engaged more in the roles of Volunteer, Caregiver, Family Member and Religious Participant than the ones whose monthly incomes are up to 3 and from 3 to 5 minimum salaries.

No significant differences in depressive symptomatology were verified on the basis of involvement of occupational roles in the Past, Present, or Future.

\section{Discussion}

\subsection{Demographic, socioeconomic, and health characteristics}

The participants were predominantly in younger age brackets, whites, Catholic, married, and professionally inactive, in accordance with the literature (CAMARANO, 2002; INSTITUTO..., 2011). Although indicators of schooling and income were low, they were above the national average, which show that almost $1 / 3$ of older people in Brazil have less than one year of formal education, and $43.2 \%$ have per capita household monthly incomes below one minimum wage (INSTITUTO..., 2010). There was a balance between the numbers of men and women; this differs from most studies in gerontology, which have samples comprised predominantly or exclusively of women, mainly on account of their higher longevity (ORGANIZAÇÃO..., 2005)

Table 2. Number of occupational roles in the Past, Present and Future $(\mathrm{n}=67)$.

\begin{tabular}{cccccc}
\hline Time scheme & Means & SD & Maximum & Minimum & Median \\
\hline Past & $5.3^{*}$ & 2.1 & 10 & 1 & 5 \\
Present & $4.4^{*}$ & 1.6 & 8 & 1 & 4 \\
Future & $4.7^{*}$ & 1.6 & 9 & 1 & 4 \\
\hline
\end{tabular}

Note: SD - Standard Deviation. *Significant difference between past, present and future $(\mathrm{p}=0.0010)$ by the Friedman Test. Significant difference between past and present $(p=0.0000)$, past and future $(p=0.0057)$, present and future $(p=0.0130)$ by the Wilcoxon Test. Source: Elaborated by the authors. 
and more involvement in projects related to aging (RESENDE et al., 2011).

The prevalence of probable depression (GDS score $>$ or $=6$ ) was $10.4 \%$, less than the figures found in the literature, which are about $15-35 \%$ in older people residing in the community (OLIVEIRA; GOMES; OLIVEIRA, 2006). The average of one illness per individual was also below the national average (more than three illnesses per older person) (INSTITUTO..., 2010). However, the study's participants were privileged compared to the

Table 3. Distribution of occupational roles over time $(\mathrm{n}=67)$.

\begin{tabular}{|c|c|c|c|c|c|c|}
\hline \multirow{2}{*}{$\begin{array}{c}\text { Occupational } \\
\text { roles }\end{array}$} & \multicolumn{2}{|c|}{ Past } & \multicolumn{2}{|c|}{ Present } & \multicolumn{2}{|c|}{ Future } \\
\hline & $\mathrm{n}$ & $\%$ & $\mathrm{n}$ & $\%$ & $\mathrm{n}$ & $\%$ \\
\hline Student & 11 & 16 & 1 & 1 & 6 & 9 \\
\hline Worker & 61 & 91 & 17 & 25 & 20 & 30 \\
\hline Volunteer & 19 & 28 & 16 & 24 & 17 & 25 \\
\hline Caregiver & 42 & 63 & 24 & 36 & 24 & 36 \\
\hline $\begin{array}{c}\text { Home } \\
\text { Maintainer }\end{array}$ & 47 & 70 & 63 & 94 & 62 & 93 \\
\hline Friend & 37 & 55 & 36 & 54 & 41 & 61 \\
\hline $\begin{array}{l}\text { Family } \\
\text { Member }\end{array}$ & 53 & 79 & 51 & 76 & 54 & 81 \\
\hline $\begin{array}{l}\text { Religious } \\
\text { Participant }\end{array}$ & 20 & 30 & 14 & 21 & 16 & 24 \\
\hline $\begin{array}{l}\text { Hobbyist/ } \\
\text { Amateur }\end{array}$ & 51 & 76 & 67 & 100 & 67 & 100 \\
\hline $\begin{array}{l}\text { Participant in } \\
\text { Organizations }\end{array}$ & 15 & 22 & 7 & 10 & 7 & 10 \\
\hline
\end{tabular}

Source: Elaborated by the authors.

Table 4. Distribution of the degree of importance of the occupational roles $(n=67)$.

\begin{tabular}{|c|c|c|c|c|c|c|}
\hline \multirow{2}{*}{$\begin{array}{l}\text { Occupational } \\
\text { roles }\end{array}$} & \multicolumn{2}{|c|}{$\begin{array}{l}\text { Not at all } \\
\text { valuable }\end{array}$} & \multicolumn{2}{|c|}{$\begin{array}{c}\text { Somewhat } \\
\text { valuable }\end{array}$} & \multicolumn{2}{|c|}{$\begin{array}{c}\text { Very } \\
\text { valuable }\end{array}$} \\
\hline & $\mathrm{n}$ & $\%$ & $\mathrm{n}$ & $\%$ & $\mathbf{n}$ & $\%$ \\
\hline Student & 3 & 4 & 2 & 3 & 62 & 93 \\
\hline Worker & 3 & 4 & 5 & 7 & 59 & 88 \\
\hline Volunteer & 5 & 7 & 10 & 15 & 52 & 78 \\
\hline Caregiver & 4 & 6 & 6 & 9 & 57 & 85 \\
\hline Home & 1 & 1 & 7 & 10 & 59 & 88 \\
\hline \multicolumn{7}{|l|}{ Maintainer } \\
\hline Friend & 8 & 12 & 14 & 21 & 45 & 67 \\
\hline $\begin{array}{l}\text { Family } \\
\text { Member }\end{array}$ & 2 & 3 & 4 & 6 & 61 & 91 \\
\hline $\begin{array}{l}\text { Religious } \\
\text { Participant }\end{array}$ & 7 & 10 & 15 & 22 & 45 & 67 \\
\hline $\begin{array}{l}\text { Hobbyist/ } \\
\text { Amateur }\end{array}$ & 0 & 0 & 7 & 10 & 60 & 90 \\
\hline $\begin{array}{l}\text { Participant in } \\
\text { Organizations }\end{array}$ & 17 & 25 & 18 & 27 & 32 & 48 \\
\hline
\end{tabular}

Table 5. Occupational roles were associated to demographic, socioeconomic, and health factors in Past.

\begin{tabular}{cc}
\hline $\begin{array}{c}\text { Demographic, } \\
\text { socioeconomic, } \\
\text { and health factors }\end{array}$ & Occupational roles \\
\hline $\begin{array}{c}\text { Gender* } \\
\text { Male }\end{array}$ & $\begin{array}{c}\text { Worker } \\
\text { Caregiver }\end{array}$ \\
Female & Home Maintainer \\
Female & Family Member \\
Marital status* & \\
Non-married & Student \\
Non-married & Volunteer \\
Non-married & Friend \\
Education** & \\
+8 years & Student \\
+8 years & Volunteer \\
+8 years & Friend \\
+8 years & Participant in \\
Income** & Organizations \\
$>5 \mathrm{MW}^{1}$ & \\
$>5 \mathrm{MW}^{1}$ & Student \\
& Participant in \\
Family arrangement $*$ & Organizations \\
Live alone & Student \\
Live alone & Volunteer \\
Presence of illnesses * & \\
Refer & Student \\
\hline
\end{tabular}

${ }^{1} \mathrm{MW}-$ minimum wage. ${ }^{*} \mathrm{p} \leq .05$ by the Fisher's exact test. ** $\mathrm{p} \leq .05$ by the Chi-square test. Source: Elaborated by the authors.

Table 6. Occupational roles were associated to demographic, socioeconomic, and health factors in Present.

\begin{tabular}{cc}
\hline $\begin{array}{c}\text { Demographic, } \\
\text { socioeconomic, } \\
\text { and health factors }\end{array}$ & Occupational roles \\
\hline $\begin{array}{c}\text { Gender* } \\
\text { Male } \\
\text { Age** } \\
70-74 \text { years } \\
\text { Education** } \\
+8 \text { years } \\
\text { Income** }\end{array}$ & Worker \\
$>5 \mathrm{MW}^{1}$ & Camily Member \\
$>5 \mathrm{MW}^{1}$ & Volunteer \\
$>5 \mathrm{MW}^{1}$ & Caregiver \\
$>5 \mathrm{MW}{ }^{1}$ & Family Member \\
Occupational status* & Religious Participant \\
Active & Religious Participant \\
Physical activity* & Worker \\
Not practice & Religious Participant \\
Not practice & \\
\hline${ }^{1} \mathrm{MW}-$ minimum wage. ${ }^{*} \mathrm{p} \leq .05$ by the Fisher's exact test. \\
${ }^{* *} \mathrm{p} \leq .05$ by the Chi-square test. Source: Elaborated by \\
the authors.
\end{tabular}


Table 7. Occupational roles were associated to demographic, socioeconomic, and health factors in Future.

\begin{tabular}{cc}
\hline $\begin{array}{c}\text { Demographic, } \\
\text { socioeconomic, } \\
\text { and health factors }\end{array}$ & Occupational roles \\
\hline $\begin{array}{c}\text { Education** } \\
+8 \text { years }\end{array}$ & Caregiver \\
Income** & \\
$>5 \mathrm{MW}^{1}$ & Volunteer \\
$>5 \mathrm{MW}^{1}$ & Caregiver \\
$>5 \mathrm{MW}^{1}$ & Family Member \\
$>5 \mathrm{MW}^{1}$ & Religious Participant \\
Occupational status* & \\
Active & Worker \\
Active & Religious Participant \\
Physical activity* & \\
Not practice & Worker \\
Practice & Friend \\
\hline${ }^{*} \mathrm{MW}-$ minimum wage. $* \mathrm{p} \leq .05$ by the Fisher's exact test. \\
the authors.
\end{tabular}

overall older Brazilian population, as they have had opportunities to obtain sociopolitical information and live in a city with positive socioeconomic indicators: high rates of education, longevity, higher wages, better healthcare, and a positive lifestyle.

\subsection{Occupational roles}

The occupational roles of the participants changed over time, corroborating with other studies in the field (ELLIOTT; BARRIS, 1987; WATSON; AGER, 1991; MCKENNA; BROOME; LIDDLE, 2007). In the present study, the average number of roles lost was 0.9, a number similar to the 0.7 found by Elliott and Barris (1987) but below the average loss of two roles shown by McKenna, Broome and Liddle (2007).

There is evidence that the older adults usually lose roles because of biological, psychological, and social changes due their own aging process. Gerontological literature highlights that the decadence of function and body structure, diseases increase, retirement, loneliness, lack of jobs opportunities, financial difficulties, fear of death as well as environmental barriers, may cause an impact on the social engagement of the older adults population (SILVA; GÜNTHER, 2000; KIELHOFNER, 2008; MCKENNA; BROOME; LIDDLE, 2007; MCLNTYRE; ATWAL, 2007; GÜNTHER, 2009).

According to Günther (2009), the reduction in social interactions is the result that comes from a selection process throughout life, during which, in a strategic and adaptive way, people choose with whom they wish to interact in order to maximize their gains and minimize social and emotional risks. The interaction that occurs between individuals and their environment is dynamic and reciprocal. It is influenced by historical, social and cultural contexts (FONSECA, 2007). In this way, we must not ignore the fact that social patterns reflect on people's actions, many times in an imposing manner (PAIS, 2007).

In general, the older adults believe that the future has short time perspective (DEPS, 2009). Contrary to this observation, we found that participants intended to broaden their occupational roles in the future. McKenna, Broome and Liddle (2007) also suggested that the older people commonly expect not to lose roles in the Future, and some even desire to broaden them. Such positive expectations of the future, even when not established and subject to change, indicate room for change intended to promote health and reinforces the premise of active aging. Furthermore, it makes clear the need to question negative stereotypes related to old age, such as inactivity and uselessness, which are factors that can lead to social exclusion (DEPS, 2009).

For the occupational therapist, redemption of or the addition of new roles to older adults' lives may be extremely important, since the performance in occupational roles could enable individuals to participate in the society and guarantee their satisfaction when they fulfill their needs and attain their goals (BRÄNHOLM; FUGL-MEYER, 1994; CRUZ, 2012).

The numbers of roles performed presented large variation through time, showing the heterogeneity of the individuals in the study. Notwithstanding their diversity, the group showed similarities in their involvement in given occupational roles.

It has been verified that in the Past the roles adopted the least were Participant in Organizations and Volunteer, as evidenced by Elliott and Barris (1987). However, the above authors highlight the role of Student as one performed the most by the older adults in the Past, contrary to the results obtained in this study. Such inequalities possibly occurred due to the time scheme used.

In addition to the role of Student, the roles of Worker and Hobbyist/Amateur were the most-performed roles in the Past in the study by Elliott and Barris (1987) and in this study. The role of Family Member "[...] involves spending time or doing something with a family member such as a child, spouse, parent, or other relative [...]" (CORDEIRO, 2005, p. 64), 
which was widely quoted in this study, was the fifth most common role named in the North American study. The role of Religious Participant, the most common role in the research by Elliott and Barris (1987), was mentioned seventh most commonly in our study. A possible reason for this fact may be associated with the difference in determining time scheme or with the cultural differences between the two countries.

In the Present, our participants are involved in an average of $4.4(\mathrm{SD}=1.6)$ roles. This number was higher than the average of $3.4(\mathrm{SD}=1.5)$ found by Watson and Ager (1991), but below the averages of $5.46(\mathrm{SD}=1.6)$ and $6.0(\mathrm{SD}=1.9)$ revealed by Elliott and Barris (1987) and McKenna, Broome and Liddle (2007), respectively. The time scheme utilized in each study, the temporal disparity between these studies and the sociocultural characteristics of the participants may be related to the disparateness in average numbers of the occupational roles performed.

The role of Hobbyist/Amateur was also shown to be the most-performed role in the study by Elliott and Barris (1987). Other studies in the field have also shown that the roles of Home Maintainer and Family Member are the main roles performed by the older adult at the Present. Besides the roles of Hobbyist/Amateur, Home Maintainer, and Family Member, the literature highlights participation in the role of Friend, which in this study presented an average engagement rate (ELLIOTT; BARRIS, 1987; WATSON; AGER, 1991; MCKENNA; BROOME; LIDDLE, 2007).

Just as indicated by the literature, the role of Student was one of the least performed at the Present by the aged population in the study (ELLIOTT; BARRIS, 1987; WATSON; AGER, 1991; MCKENNA; BROOME; LIDDLE, 2007). Only the study by Watson and Ager (1991) found significant results with respect to the role of Participant in Organizations, describing little participation. The studies by Watson and Ager (1991) and McKenna, Broome and Liddle (2007) also mention the role of Religious Participant as one of the least performed.

In the Future, the subjects wish to broaden or maintain participation in occupational roles with more focus on the roles of Student and Friend. Nowadays, an increasing number of older adults have resisted to the negative changes associated to the aging process, and have created a more integrated and participative life style (FERRIGNO, 2007). Therefore, the development of programs for older adults, such as senior citizens' universities and community centers, can be viable and efficient alternatives to broaden possibilities for socioeducational care and social interaction.

\subsection{Value attributed to occupational roles}

The older adults generally attribute a high degree of importance to all occupational roles (ELLIOTT; BARRIS, 1987; WATSON; AGER, 1991; MCKENNA; BROOME; LIDDLE, 2007). This attitude may be related to the aging process in which individuals attribute gaining life experience. A search for a better understanding and acceptance of themselves enables them to have a wider and more positive view of life (LUZ; AMATUZZI, 2008; NERI, 2008), circumstances also described in recent aging theories (BALTES; BALTES, 1991; TORNSTAM, 2005). However, it is important to state that a limitation of the Role Checklist may have influenced this result. Part II of the instrument repeats the occupational roles of Part I, an aspect that can possibly reduce the interest and attention of the participants to answer this part of the assessment as they may find it redundant (COLÓN; HAERTLEIN, 2002).

Older adults tend to attribute more value to the occupational roles they perform, reinforcing feelings of satisfaction and personal effectiveness, and thus a high sense of self-worth (ELLIOTT; BARRIS, 1987). However, the results of this study showed a certain contradiction between the real engagement of the older adult in the Present and the attributed value at the roles. Although the three roles they perform the most (Hobbyist/Amateur, Home Maintainer, and Family Member) are among the five roles described as being Very valuable, the roles of Student and Worker, which were also highly valued, presented low performance frequencies. This fact may be linked to the future perspective of the older adults. They plan to increase their involvement in the latter two roles, based on the importance that these roles had in the past, or because of social expectations and cultural values prioritized as part of a productive life (CARLOS; JACQUES; LARRATÉA, 1999). It can be noted that cultural differences and personal and socio-economic factors can produce differences in the perception of engagement and development of occupational roles as a whole (RIBEIRO et al., 2009; DEPS, 2009).

\subsection{Occupational roles and demographic, socioeconomic, and health data}

When occupational roles and gender were compared, differences in the involvement of some roles were verified, such as that shown by previous studies (MCKINNON, 1992; STANLEY, 1995; SILVA; 
GÜNTHER, 2000; RIBEIRO et al., 2009). In Past, men were more involved in the role of Worker and women in the roles of Caregiver, Home Maintainer, and Family Member. These results reflect the influences of demarcations between genders, produced by sociocultural expectations linking the male universe to the public domain and the female universe to the home private world (FERNANDES, 2009; GUTIERREZ; MINAYO, 2010). In the Present, we noticed a significant difference only in the role of Worker for men, while in the Future, no gender differences were verified, indicating that the differences between genders may have decreased over the years. With the advent of retirement, men may be expected to share housework responsibilities with women, increasing their participation in family reunions, and/or dedicating more time to taking care of the spouse (SANTOS; DIAS, 2008).

With regard to age, no significant differences were verified between the groups cited except for the role of Family Member in the Present. Participants ages 70-74 were more engaged in the role of Family Member compared to the groups between the ages of $75-79$ and $80-84$ years. This may be related to the lower probability of widowhood at early ages.

Although McKenna, Broome and Liddle (2007) did not assess the involvement of age in occupational roles specifically, they did not verify any significant differences in the number of occupational roles among age categories $(65-74,75-84$, and $\geq 85$ years). Ribeiro et al. (2009), while reviewing the relationship between age bracket and activity performance, showed that older adults perform instrumental activities of daily life less frequently. However, no differences were verified among the groups (60-69, $70-79$ and $\geq 80$ years old) in the practice of physical, social, and intellectual activities.

Non-married older people were more engaged in the roles of Student, Volunteer, and Friend than the married ones. Perhaps these differences are associated with non-married older adults' higher autonomy in performing external roles. Another factor was that the non-married group was prominently comprised of women; this may have influenced the final outcome, as the women in our study had a higher education level, and in accordance with the literature, were more involved in socioemotional roles (DOLL et al., 2007).

Having reached 8 or more years of schooling was related to engaging in the roles of Student, Volunteer, Friend, and Participant in Organizations in Past. The older adults with this characteristic may be in a more privileged position with regard to acquiring information and being aware of political and social issues. In addition to this, they may have more availability of financial resources to engage in social activities, as more schooling is usually linked to a better income (SILVA; GÜNTHER, 2000; RIBEIRO et al., 2009). The literature ratifies that higher levels of education, specifically, contribute to the development of the role of Volunteer (LOPES, 2006; SOUZA, 2007).

In Present and Future, higher levels of education (8 or more years of schooling) were linked to the role of Caregiver. We assume that the older adults in this category were better able to perceive the needs of others and understand the importance of social support. Older adults who received further schooling attain a higher number of personal relations (SILVA; GÜNTHER, 2000).

The participants with higher incomes had more involvement in the roles of Student and Participant in Organizations in the Past. Significant engagement in the role of Student reinforces the relationship between schooling and income (SILVA; GÜNTHER, 2000). With regard to Participation in organizations it can be presumed that people with better incomes may have higher social status, and thus more likely to integrate with organizations, due to their charisma and/or social influence (NASCIMENTO, 2008).

Present and Future, the older adults with higher incomes presented significant differences in their engagement in the roles of Volunteer, Caregiver, Family Member, and Religious Participant. There is still a need for further studies to evaluate the relationship between income and engagement in certain occupational roles. However, the positive association between the individual's income with social relations is also mentioned in other studies (LEON; GLASS; BERKMAN, 2003). Martinez et al. (2006) found a relationship between higher incomes and voluntary activities. Ribeiro et al. (2009) found a relationship between income and higher engagement in intellectual activities (reading, language courses, handicraft courses, and cultural entertainment).

With regard to occupational situation, active older adults were more involved in the roles of Religious Participant in the Present and the roles of Worker and Religious Participant in the Future than were inactive individuals. Such relationships deserve more in-depth and extensive study, as they were not confirmed by the literature. We speculate that active individuals may be more willing to engage in professional activities and may seek religion for spiritual comfort to confront finiteness.

The older adults who lived alone performed the roles of Student and Volunteer in the Past more than did participants who lived with others. It is 
difficult to explain these facts only based in the collected data, as the circumstances surrounding the individuals in the past were not extensively investigated. In any event, three possible factors may explain the increased engagement of the older adults who lived alone: more availability of time to perform activities outside home, more autonomy to choose activities, and more need to search for interpersonal relationships.

There were no significant differences among the groups in terms of depressive symptomatology, which corroborates the study recently conducted by Santos (2012). There is a lack of broad studies concerning this issue, so it requires further research. Several authors have shown depressive symptomatology to be a negative influence in all stages of life, including old age (OLIVEIRA; GOMES; OLIVEIRA, 2006; BLAZER, 2009; BLAY; MARCHESONI, 2011).

The older adults who had self-reported illnesses, presented more engagement in the role of Student in the Past. The methodology used in this research was not capable of exploring the past occupational description in full detail. Thus, there are not sufficient elements to come to an objective conclusion about that relation. The older adults with higher levels of education may have more information about illnesses and their consequences, and therefore express their symptoms more easily, obtain diagnoses, and have better opportunities to access services for treatment and therapeutic follow-up. Furthermore, Lima-Costa (2004) highlighted the positive influence education has on people in matters such as the individual's decreased exposure to a sedentary lifestyle, unhealthy diets, smoking and alcohol abuse.

Regarding to the practice of physical activity, the older adults who did not perform physical activities (sedentary) reported more engagement in the role of Worker in the Present and in the Future and increased engagement in the role of Religious Participant in the Present, while the ones who practiced physical activities (non-sedentary) tended to anticipate more involvement in the role of Friend in the Future. This might be explained by the fact that the older adults remaining in the workforce may not have available time and energy to dedicate themselves to physical activities. Regarding the roles of Religious Participant and Friend, we do not have a perspective on ways to explain their occurrence, but it may be related to a search for social support.

\subsection{Limitations}

The results are not conclusive, especially because they are part of a cross-sectional study. The individuals were not chosen randomly. An important limitation was the specific composition of the sample: it was comprised only of independent, individuals between the ages of 70 and 84 years who participated in an Association of Retirees and lived in a medium-sized city in the countryside of Sáo Paulo, Brazil. The sample imbalance amongst some subgroups, the time scheme utilized and the objectivity during data collection on occupational roles, may also limit the effectiveness of the study.

\subsection{Future research}

Although the results in the present study show important information to be considered regarding this population, studies with wider samples and more diverse groups need to be conducted to enable generalization of the data observed and expansion of knowledge. We need to disprove, confirm, or raise other hypotheses concerning to which variables may be related to the development of occupational roles in old age. Although they are difficult to implement, it would be interesting to conduct cohort studies to follow up on the trends and development of the aging process. Qualitative methods may also be employed to explore the occupational behavior of individuals in different contexts of life. In addition to empirical advances, the theoretical implications of this theme need to be clarified.

\section{Conclusion}

The present study promoted the understanding of the occupational performance of older adult in Brazil and its relationship with demographic, socioeconomic and health factors. The occupational roles changed within the time period analyzed. The loss of roles between the Past-Present and between the Past-Future was evident. In spite of this loss, the interest of the older adults in acquiring roles in the Future was verified.

In general, occupational roles were associated with specific demographic, socioeconomic, and health factors. In the Past, the occupational roles were associated with gender, marital status, schooling, income, family arrangement, and the presence of illnesses; in the Present, they were associated with gender, age, schooling, income, occupational status, and practice of physical activity; in the Future, occupational roles were associated with schooling, income, occupational status, and practice of physical activity. People with higher incomes and levels of education were more likely to have a higher level of engagement in occupational roles both in the Past, Present and Future. 
The study shows relevance as it draws attention to understanding the occupational universe, once the field of occupational therapy is characterized by health promotion and the participation of individuals through involvement in meaningful occupations. Part of the job performed by the occupational therapist with older adults in diverse care arrangements could focus more intensely on the occupational careers of older adults, their interests and goals; and also help them, when necessary, in the use of selection, optimization and compensation strategies. They could aim specially on the maintenance, recuperation, and/or enhancement of essential occupational roles for each individual or population group.

This exploratory character research may also contribute to other areas of knowledge, as it sheds light on the diversity and complexity of the older adults' participation in society, and thus discusses social aging. In addition, this research indicates that there is room for actions intended to promote health and a need to recognize the diversity of individuals in order to plan public policies towards active aging.

\section{Acknowledgements}

The authors thank the Association of Retirees for allowing us to conduct the study, as well as the participants for their trust and dedicating their time for the procedures. We would also like to express warm gratitude to Thelma Simóes Matsukura (Federal University of São Carlos, Brazil), Maria Helena Morgani de Almeida (University of São Paulo, Brazil), and Paula Costa Castro (Federal University of São Carlos, Brazil) for their assistance during the process of planning the study.

\section{References}

AMERICAN OCCUPATIONAL THERAPY ASSOCIATION - AOTA. Occupational therapy practice framework: domain e process 2 nd ed. The American Journal of Occupational Therapy, Boston, v. 62, n. 6, p. 625683, 2008. http://dx.doi.org/10.5014/ajot.62.6.625

BALTES, P. B.; BALTES, M. M. Psychological perspectives on successful aging: the model of selective optimization with compensation. In: BALTES, P. B.; BALTES, M. M. Successful aging: perspectives from the behavioral sciences. New York: Cambridge University Press, 1991. p.1-34.

BLACK, M. M. The occupational career. The American Journal of Occupational Therapy, Boston, v. 30, n. 4, p. 225-228, 1976. PMid:937464.

BLAY, S. L.; MARCHESONI, M. S. M. Association among physical, psychiatric and socioeconomic conditions and WHOQOL-Bref scores. Cadernos de Saúde
Pública, Rio de Janeiro, v. 27, n. 4, p. 677-686, 2011. PMid:21603751.

BLAZER, D. G. Depression in late life: review and commentary. Winter, [s.1.], v. 7, n. 1, p. 118-136, 2009. http://dx.doi.org/10.1176/foc.7.1.foc118.

BRÄNHOLM, I. B.; FUGL-MEYER, A. R. On non-work activity preferences: relationships with occupational roles. Disability and Rehabilitation, [s.l.], v. 16, n. 4, p. 205-216, 1994. http://dx.doi. org/10.3109/09638289409166614. PMid:7812021.

BRITO, F. C.; NUNES, M. I.; YUASO, D. R. Multidimensionality in gerontology II: assessment instruments. In: PAPALÉO NETTO, M. Tratado de gerontologia. São Paulo: Editora Atheneu, 2007. p. 133-147.

BRUCKI, S. M. D. et al. Sugestóes para o uso do mini-exame do estado mental no Brasil. Arquivos de Neuro-Psiquiatria, São Paulo, v. 61, n. 3B, p. 777-781, 2003. http://dx.doi.org/10.1590/S0004282X2003000500014.

CADERNOS DE TERAPIA OCUPACIONAL DA UFSCar. Available from: <http://www.cadernosdeterapiaocupacional.ufscar.br/index.php/cadernos $>$. Access on: 20 apr. 2014.

CAMARANO, A. A. Envelhecimento da populaçấo brasileira: uma contribuição demográfica. In: FREITAS, E. V. et al. Tratado de geriatria e gerontologia. Rio de Janeiro: Guanabara Koogan, 2002. p. 58-71.

CARLOS, S. A.; JACQUES, M. G. C.; LARRATÉA, S. V. Identidade, aposentadoria e terceira idade. Estudos Interdisciplinares sobre o Envelhecimento, Porto Alegre, v. 84, n. 1, p. 77-89, 1999.

CENTRO LATINO-AMERICANO E DO CARIBE DE INFORMAÇÃO EM CIÊNCIAS DA SAÚDE BIREME. Biblioteca Virtual em Saúde. Available from: $<$ http://regional.bvsalud.org/php/index.php $>$. Access on: 20 apr. 2014.

COLÓN, H.; HAERTLEIN, C. Spanish translation of the role checklist. The American Journal of Occupational Therapy, Boston, v. 56, n. 5, p. 586-589, 2002. http:// dx.doi.org/10.5014/ajot.56.5.586. PMid:12269515.

COORDENAÇÃO DE APERFEIÇOAMENTO DE PESSOAL DE NÍVEL SUPERIOR - CAPES. Banco de teses. Available from: <http://capesdw.capes.gov. $\mathrm{br} /$ ?login-url-success=/capesdw/>. Access on: 20 apr. 2014.

CORDEIRO, J. J. R. Validação da Lista de Identificação de Papéis Ocupacionais em pacientes portadores de doença pulmonar obstrutiva crônica (DPOC). 2005. 123 f. Dissertação (Mestrado em Ciências da Saúde) - Universidade Federal de São Paulo, São Paulo, 2005.

CORDEIRO, J. R. et al. Cross-cultural reproducibility of the Brazilian Portuguese version of the Role Checklist for persons with chronic obstructive pulmonary disease. The American Journal of Occupational Therapy, Boston, 
v. 61, n. 1, p. 33-40, 2007. http://dx.doi.org/10.5014/ ajot.61.1.33. PMid:17302103.

CRUZ, D. M. C. Papéis ocupacionais e pessoas com deficiências físicas: independência, tecnologia assistiva e poder aquisitivo. 2012. $230 \mathrm{f}$. Tese (Doutorado em Educação Especial) - Universidade Federal de São Carlos, São Carlos, 2012.

DEPS, V. L. Atividade e bem-estar psicológico na maturidade. In: NERI, A. L. (Ed.). Qualidade de vida e idade madura. Campinas: Papirus, 2009. p. 57-82.

DICKERSON, A. E.; OAKLEY, F. Comparing the roles of community-living persons and patient populations. The American Journal of Occupational Therapy, Boston, v. 49, n. 3, p. 221-228, 1995. http://dx.doi. org/10.5014/ajot.49.3.221. PMid:7741155.

DOLL, J. et al. Atividade, desengajamento, modernização: teorias sociológicas clássicas sobre o envelhecimento. Estudos Interdisciplinares sobre o Envelhecimento, Porto Alegre, v. 12, p. 7-33, 2007. http://dx.doi. org/10183/27274

ELLIOTT, M. S.; BARRIS, R. Occupational role performance and life satisfaction in elderly persons. Occupational Therapy Journal of Research, Bethesda, v. 7, n. 4, p. 215-224, 1987.

FERNANDES, M. G. M. Papéis sociais de gênero na velhice: o olhar de si e do outro. Revista Brasileira de Enfermagem, Brasília, v. 62, n. 5, p. 705-710, 2009. http:// dx.doi.org/10.1590/S0034-71672009000500009.

FERRIGNO, J. C. Co-educação entre geraçóes: do conflito ao desenvolvimento da solidariedade. In: PAPALÉO NETTO, M. Tratado de gerontologia. São Paulo: Editora Atheneu, 2007. p. 233-242.

FOLSTEIN, M. F.; FOLSTEIN, S. E.; MCHUGH, P. R. "Mini-mental state". A practical method for grading the cognitive state of patients for the clinician. Journal of Psychiatric Research, Oxford, v. 12, n. 3, p. 189-198, 1975. http://dx.doi.org/10.1016/00223956(75)90026-6. PMid:1202204.

FONSECA, A. M. Subsídios para uma leitura desenvolvimental do processo de envelhecimento. Psicologia: Reflexão e Crítica, Porto Alegre, v. 20, n. 2, p. 277-289, 2007.

FREITAS, M. C. et al. Perspectivas das pesquisas em gerontologia e geriatria: revisão da literatura. Revista Latino-Americana de Enfermagem, São Paulo, v. 10, n. 2, p. 221-228, 2002. http://dx.doi.org/10.1590/S010411692002000200015 . PMid:12138568.

GÜNTHER, I. A. Envelhecimento, relaçóes sociais e ambiente. In: FALCÃO, D. V. S.; ARAÚJO, L. F. Psicologia do envelhecimento: relaçóes sociais, bem-estar subjetivo e atuação profissional em contextos diferenciados. Campinas: Editora Alínea, 2009. p. 11-26.

GUTIERREZ, D. M. D.; MINAYO, M. C. S. Produção de conhecimento sobre cuidados da saúde no âmbito da família. Ciência \& Saúde Coletiva, Rio de Janeiro, v. 15, n. 1, p. 1497-1508, 2010. http://dx.doi.org/10.1590/ S1413-81232010000700062

HÅKANSSON, C. et al. Well-being and occupational roles among middle-aged women. Work, Amsterdam, v. 24, n. 4, p. 341-351, 2005. PMid:15920309.

INSTITUTO BRASILEIRO DE GEOGRAFIA E ESTATÍSTICA - IBGE. Indicadores sociodemográficas e de saúde no Brasil. Rio de Janeiro: IBGE, 2009. Available from: <http://www.ibge.gov.br/home/estatistica/populacao/indic_sociosaude/2009/indicsaude.pdf>. Access on: 20 apr. 2014.

INSTITUTO BRASILEIRO DE GEOGRAFIA E ESTATÍSTICA - IBGE. Sintese de Indicadores sociais: uma análise das condições de vida da população brasileira. Rio de Janeiro: IBGE, 2010. Available from: <http:// www.ibge.gov.br/home/estatistica/populacao/condicaodevida/indicadoresminimos/sinteseindicsociais 2010/ SIS_2010.pdf>. Access on: 20 apr. 2014.

INSTITUTO BRASILEIRO DE GEOGRAFIA E ESTATÍSTICA - IBGE. Sinopse do Censo 2010. Rio de Janeiro: IBGE, 2011. Available from: <http://biblioteca.ibge.gov.br/visualizacao/livros/liv49230.pdf>. Access on: 20 apr. 2014.

INSTITUTO BRASILEIRO DE INFORMAÇÃO EM CIÊNCIA E TECNOLOGIA - IBICT. Bilbioteca Digital Brasileira de Teses de Dissertaçóes. Availabre from: <http://bdtd.ibict.br/vufind/>. Access on: 20 apr. 2014.

IRIGARAY, T. Q.; SCHNEIDER, R. H. Impacto na qualidade de vida e no estado depressivo de idosas participantes de uma universidade da terceira idade. Estudos de Psicologia, Campinas, v. 25, n. 4, p. 517-525, 2008. http://dx.doi.org/10.1590/S0103166X2008000400006.

KATZ, S.; AKPOM, C. A. A measure of primary sociobiological functions. International Journal of Health Services, Westport, v. 6, n. 3, p. 493-508, 1976. http:// dx.doi.org/10.2190/UURL-2RYU-WRYD-EY3K. PMid:133997.

KIELHOFNER, G. Model of human occupation: theory and application. Baltimore: Lippincott Williams \& Wilkins, 2008.

LEON, C. F. M.; GLASS, T. A.; BERKMAN, L. F. Social engagement and disability in a community population of older adults: the New Haven EPESE. American Journal of Epidemiology, Baltimore, v. 157, n. 7, p. 633-642, 2003. http://dx.doi.org/10.1093/aje/kwg028. PMid:12672683.

LIMA-COSTA, M. F. A escolaridade afeta, igualmente, comportamentos prejudiciais à saúde de idosos e adultos mais jovens? - Inquérito de Saúde da Regiāo Metropolitana de Belo Horizonte, Minas Gerais, Brasil. Epidemiologia e Serviços de Saúde, Brasília, v. 13, n. 4, p. 201-208, 2004 . 
LOPES, A. Trabalho voluntário e envelhecimento: um estudo comparativo entre idosos americanos e brasileiros. 2006. 230 f. Tese (Doutorado em Educação) - Universidade Estadual de Campinas, Campinas, 2006.

LOURENÇO, R. A.; VERAS, R. P. Mini-Mental state examination: psychometric characteristics in elderly outpatients. Revista de Saúde Pública, São Paulo, v. 40, n. 4, p. 712-719, 2006. PMid:16906312.

LUZ, M. M. C.; AMATUZZI, M. M. Vivências de felicidade de pessoas idosas. Estudos de Psicologia, Campinas, v. 25, n. 2, p. 303-307, 2008. http://dx.doi. org/10.1590/S0103-166X2008000200014.

MARTINEZ, I. L. et al. Engaging older adults in high impact volunteering that enhances health: recruitment and retention in The Experience Corps Baltimore. Journal of Urban Health, Cary, v. 83, n. 5, p. 941-953, 2006. http://dx.doi.org/10.1007/s11524-006-9058-1. PMid:16758336.

MCKENNA, K.; BROOME, K.; LIDDLE, J. What older people do: time use and exploring the link between role participation and life satisfaction in people aged 65 years and over. Australian Occupational Therapy Journal, Victoria, v. 54, n. 4, p. 273-284, 2007. http://dx.doi. org/10.1111/j.1440-1630.2007.00642.x.

MCKINNON, A. L. Time use for self care, productivity, and leisure among elderly Canadians. Canadian Journal of Occupational Therapy, Ottawa, v. 59, n. 2, p. 102-110, 1992. http://dx.doi. org/10.1177/000841749205900206.

MCLNTYRE, A.; ATWAL, A. Terapia ocupacional e a terceira idade. São Paulo: Editora Santos, 2007.

NASCIMENTO, A. R. B. Escolhas e decisöes: estudo do processo participativo em organizaçóes da economia solidária. 2008. 208 f. Dissertação (Mestrado em Administração) - Universidade Metodista de São Paulo, São Bernardo do Campo, 2008.

NERI, A. L. Palavras-chave em gerontologia. Campinas: Editora Alínea, 2008.

OAKLEY, F. et al. The role checklist: development and empirical assessment of reliability. The Occupational Therapy Journal of Research, Bethesda, v. 6, n. 3, p. 157170, 1986.

OLIVEIRA, D. A. A. P.; GOMES, L.; OLIVEIRA, R. F. Prevalence of depression among the elderly population who frequent community centers. Revista de Saúde Pública, São Paulo, v. 40, n. 4, p. 734-736, 2006. http:// dx.doi.org/10.1590/S0034-89102006000500026. PMid:17063251.

ORGANIZAÇÃO MUNDIAL DA SAÚDE - OMS. Envelhecimento ativo: uma política de saúde. Brasília: Organização Pan-Americana da Saúde, 2005. Available from: <http://bvsms.saude.gov.br/bvs/publicacoes/envelhecimento_ativo.pdf>. Access on: 20 apr. 2014.
PAIS, J. M. Cotidiano e reflexividade. Educação \& Sociedade, Campinas, v. 28, n. 98, p. 23-46, 2007. http:// dx.doi.org/10.1590/S0101-73302007000100003.

PARADELA, E. M. P.; LOURENÇO, R. A.; VERAS, R. P. Validation of geriatric depression scale in a general outpatient clinic. Revista de Saúde Pública, São Paulo, v. 39, n. 6, p. 918-923, 2005. PMid:16341401.

QUEIROZ, Z. P. V.; PAPALÉO NETTO, M. Envelhecimento bem-sucedido: aspectos biológicos, psicológicos e socioculturais. Importância da sociabilidade e da educação. In: PAPALÉO NETTO, M. Tratado de gerontologia. São Paulo: Editora Atheneu, 2007. p. 807-816.

RESENDE, M. C. et al. Saúde mental e envelhecimento. Psico PUCRS, Porto Alegre, v. 42, n. 1, p. 31-40, 2011.

REVISTA DE TERAPIA OCUPACIONAL DA UNIVERSIDADE DE SÁO PAULO. Available from: <http://www.revistas.usp.br/rto/>. Access on: 20 apr. 2014.

RIBEIRO, P. C. C. et al. Variabilidade no envelhecimento ativo segundo gênero, idade e saúde. Psicologia em Estudo, Maringá, v. 14, n. 3, p. 501-509, 2009. http:// dx.doi.org/10.1590/S1413-73722009000300011.

SANTOS, C. A. V. Identificação de papéis ocupacionais e sintomas depressivos em idosos. 2012. 103 f. Dissertação (Mestrado em Saúde na Comunidade) - Universidade de São Paulo, Ribeirão Preto, 2012.

SANTOS, I. E.; DIAS, C. M. S. B. Homem idoso: vivência de papéis desempenhados ao longo do ciclo vital da família. Aletheia, Canoas, v. 27, n. 1, p. 98-110, 2008.

SILVA, I. R.; GÜNTHER, I. A. Papéis sociais e envelhecimento e uma perspective de curso de vida. Psicologia: Teoria e Pesquisa, Brasília, v. 16, n. 1, p. 31-40, 2000. http://dx.doi.org/10.1590/S010237722000000100005.

SOUZA, L. M. Trabalho voluntário, saúde e qualidade de vida em idosos. 2007. 125 f. Dissertação (Mestrado em Enfermagem) - Universidade Federal do Rio Grande do Sul, Porto Alegre, 2007.

STANLEY, M. An investigation into the relationship between engagement in valued occupations and life satisfaction for elderly South Australians. Journal of Occupational Science, Australia, v. 2, n. 3, p. 100-114, 1995. http://dx.doi.org/10.1080/14427591.1995.9686400.

TORNSTAM, L. Gerotranscendence: a developmental Theory of Positive Aging. New York: Springer Publishing Company, 2005.

VAUSE-EARLAND, T. Perceptions of role assessment tools in the physical disability setting. The American Journal of Occupational Therapy, Boston, v. 45, n. 1, p. 26-31, 1991. http://dx.doi.org/10.5014/ajot.45.1.26. PMid:2000921. 
VERAS, R. Population aging today: demands, challenges and innovations. Revista de Saúde Pública, São Paulo, v. 43, n. 3, p. 548-554, 2009. http://dx.doi.org/10.1590/ S0034-89102009000300020. PMid:19377752.

VIEIRA, E. B.; KOENING, A. M. Avaliação cognitiva. In: FREITAS, E. V. et al. Tratado de geriatria e gerontologia. Rio de Janeiro: Guanabara Koogan, 2002. p. $921-$ 928.
WATSON, M. A.; AGER, C. L. The impact of role valuation and performance on life satisfaction in old age. Physical \& Occupational Therapy in Geriatrics, New York, v. 10, n. 1, p. 27-62, 1991. http://dx.doi.org/10.1080/ J148v10n01_03.

YESAVAGE, J. A.; SHEIKH, J. I. 9/Geriatric Depression Scale (GDS). Clinical Gerontologist, New York, v. 5, n. 1-2, p. 165-173, 1986. http://dx.doi.org/10.1300/ J018v05n01_09.

\section{Author's Contributions}

The authors participated in all stages of the preparation of the article.

\section{Funding Source}

This research was conducted with incentives of the Coordination for the Improvement of Higher Level Personnel (Coordenação de Aperfeiçoamento de Pessoal de Nível Superior, CAPES).

\section{Notes}

${ }^{1}$ During the research (1st semester of 2011) the minimum salary was $\mathrm{R} \$ 545.00$ per month, which was equivalent to U\$ 272.50 dollars per month. 